\title{
As psicoses não decididas da infância: um estudo psicanalítico
}

São Paulo, SP: Casa do Psicólogo, 2004

\author{
Maria Aparecida de Luna Pedrosa
}

N

decorrer da leitura ocorreu-me que Leda Bernardino estaria escrevendo sobre o que da mitologia metaforizaria um vivido. Assim, do Caos e da Noite, podendo se pensar no Real, o contexto do universo, a variedade e a diversidade de eventos em um tempo e espaço, uma apresentação ampla e infinita, a linguagem perfazendo, em uma lógica temporalizada, discursos e relações para determinarem o nascimento do sujeito. Tempo e Espaço dispostos como suportes para a definição de passagens e experiências; enfim, o vivido na experiência humana.

Nesse livro, que retrata sua tese de doutorado, a autora nos enreda de capítulo a capítulo na trama e na clínica apresentadas em seu texto, sem se arredar das categorias do tempo, de sua lógica e do estabelecimento do nascer do sujeito e do mundo subjetivo. Sua intenção é mostrar que em "um" tempo, "um" organismo adquire um ritmo de organização particular e uma estruturação, dependendo da diversidade e adversidade na ordem das relações e linguagem.

Contempla-nos com cuidadosa e elaborada apresentação sobre o olhar e a escuta em Freud, Melanie Klein, Winnicott, Bethelheim, Mahler, Meltzer, Lacan, Dolto Manonni, Tustin, Lang e outros. Olhares que se ocuparam dos signos da psicopatologia, da criança e da infância. A autora põe o leitor frente ao fundamento da condição

Psicanalista. Mestre em Psicologia Clinica USP. Prof ${ }^{a}$ aposentada da Universidade Federal do Paraná - UFPr. 


\section{Resenha}

humana, já mostrada por Freud, como ser de linguagem e pensamento, surpreendido por manifestações inconscientes. Sobreleva a importância do diagnóstico definido pela posição do sujeito e por suas modalidades de resposta à falta, ou seja, diante da castração. Apresenta-nos as estruturas e o que as caracteriza, passando a ocupar-se da Psicose e das formas como é considerada por diferentes analistas.

Leda Bernardino reapresenta a psicose como efeito de um não querer saber nada disso - a castração - como efeito da não simbolização da falta. Assim, o grande outro (A) passa a mostrarse consubstancialmente incerto, e daí o risco do vazio. Sua tese.

Além de lembrar o parecer de Lacan, para quem a psicose na criança é diferente da forma da Psicose no adulto, a autora apresenta posições de outros analistas que são bastante pontuais: angústia psicótica e defesa, em Melanie Klein; a posição educativa e adaptativa na reversão do autismo, para Tustin; o valor da restauração das relações, para Bettelheim; a importância da mãe e sua função para a prevenção da Psicose, em Winnicott; a Psicose como efeito de um modo de envelopamento da criança, Pai e Mãe num discurso coletivo, para Dolto e Mannoni; a indefinição sobre a Psicose, a Pré-Psicose, em Roger Misès; e a definição de estados parapsicóticos e borderliners, descritos por Lang.

A autora inicia suas questões em torno de um tempo. O tempo em que se inscreveria o Nome-do-Pai e a função paterna em decorrência da falta e da foraclusão. Aparece a pergunta sobre a irreversibilidade no quadro da psicose. Aparece o desafio na base da argumentação em sua exposição.

Iniciando com Lacan, observa que o psicanalista francês fala em fenômenos que rompem, surgem abruptamente, e pergunta: o que havia antes? Uma psicose não deflagrada ou um sujeito que nunca teve qualquer crise, mas tem idéias delirantes que são acompanhadas de vozes? Por que não há ruptura ou desestabilização? Joyce se explica com as suplências, uma estrutura pode mudar sua resposta. A autora mostra-nos a posição daqueles que consideram que o sujeito quando apresenta uma estrutura definida nada muda em sua estrutura, enquanto outros consideram diferenças nesse processo.

A pergunta de Leda Bernardino a propósito da temporalidade apresenta-se e insiste no seu texto. O "quando" é buscado e aparece, demonstrando-se que há um tempo, que não é o mesmo da maturação orgânica, e que nesse tempo é possível identificar a operacionalidade e a funcionalidade entre a criança e o grande outro (A). São evocadas observações de Rosine e Robert Lefort, J. A. Miller, Colette Soler, J.J.Rassial, Coriat, Jerusalinsky e outros, 
com suas posições que contribuíram para a construção da tese principal: a tese de que as psicoses não decididas apontam para as modalidades de relação ao $\mathrm{A}$, e mantendo, sempre presente a pergunta sobre um tempo, porque tem peso e valor na clínica, na medida em que este dirá onde e como se deu o furo, e apontará como restaurá-lo.

Inconsciente e atemporalidade - "um outro modo de tempo" - a razão das operações lógicas do ver, compreender e concluir, e o fenômeno de um apressar. Nesse contexto, Leda Bernardino expõe o caráter do infantil em relação ao desenvolvimento, tomado como efeito das relações com a linguagem, o a mais fundamental organizador, ao embalo e sopro do desejo do grande Outro.

O Infantil é o tempo da estrutura para Lacan. A autora desenvolve esse ponto brevemente e com precisão. Trata dos efeitos do Nome-do-Pai e da Metáfora Paterna; situa o que chamará de "momentos chave", ou seja, resumidamente apresenta quatro tempos: da escrita, do Nome-do-Pai, da estrutura e da lógica.

$\mathrm{Na}$ apresentação dos momentos-chave há a falência mais ou menos temporária do grande Outro (A), e essa falência como que arranha a montagem estrutural ou quebra-a em parte, podendo determinar a Psicose de modo definitivo ou em um limite.

Leda Bernardino instiga-nos a pensar e perguntar com mais agudeza sobre o circuito das "debilidades", porque ao demonstrar - também com o caso de uma análise apresentado no livro: o caso Hélio - a fragilidade da organização subjetiva, das apresentações de palavras na frouxidão de representações de discurso, convidanos, como leitores, ao mergulho nessa clínica, porque o texto remete-nos além de suas referências. Traz-nos a história da Psicanálise com crianças com fina reconstrução. Ao depor sobre seu lugar e ato, a autora dá provas da experiência da castração, de fato legada a nós por Freud especialmente, e pontuada vivamente por Lacan. Dá mostras das pegadas do discurso freudiano que habitam a analista. Ousa colocar na mesa a clínica de modo claro e penetrante, e oferece o tratamento àquelas ranhuras no aparelho e estrutura em curso ainda de montagem da arquitetura do sujeito. Mostra como cuidar do restabelecimento de um sujeito em risco de não ser. Convida os praticantes à revisão do que se passou a definir como casos limites.

O livro traz-nos com o caso a prova do simbólico que prima. Trata do nascimento da Infância. O tempo da criança tomada como objeto imaginário da mãe, deparando-se com o grande outro $(\mathrm{A})$, vendo-se presa dessa relação, pagando um preço, a marca do A.

118 Estilos da Clínica, 2006, Vol. XI, n²0, 116-119 


\section{Resenha}

A entrada do pai em cena, iniciando a separação com um apagamento, representado por Hélio com o lavar de seus desenhos. Aparece de modo indelével o efeito do recalcamento que faz um obstáculo, uma barra ao gozo, à relação mãe $\mathrm{x}$ bebê. Uma separação que no curso do tratamento marca um ponto de fundação de apenas uma letra - o objeto, como a, perdido, passível de existência no fantasiar, nas representações, na vida, e...

Um percurso e um encontro com a falta, a sobrevivência ancorando-se na metáfora paterna.

Com o caso, a autora nos apresenta como pôde se decidir a estrutura em um tratamento. A relação ao A se decide.

Concluo esta apresentação podendo dizer da satisfação em verificar com essa contribuição de Leda Bernardino para as possibilidades na clínica com crianças e o incentivo para aos analistas jamais cederem de seu desejo de analistas se este estiver presente, porque podemos encontrar outros - Hélios - em nossa prática. 